\title{
Ability of Non-Pathogenic Fusarium oxysporum Strain Fo47 to Suppress Rhizomania Disease of Sugar Beets in Morocco
}

\author{
Fatima NOUAYTI ${ }^{1,2}$, Ilham MADANI ${ }^{2}$, Abdessalem TAHIRI ${ }^{1 *}$, \\ Abdelali BLENZAR ${ }^{2}$, Rachid LAHLALI ${ }^{1}$ \\ ${ }^{1}$ Ecole Nationale d'Agriculture de Meknès (ENA-Meknès), Department of Plant Protection, Phytopathology Unit, Km10, \\ RteHajKaddour, BP S/40, Meknès 50001, Morocco; atabiri@enameknes.ac.ma (*correspondingauthor); rlablali@enameknes.ac.ma \\ ${ }^{2}$ Moulay Ismail University, Faculty of Sciences. Department of Biology PO Box 11201 Zitoune Meknes, \\ Morocco;fatimanouayti@gmail.com;imadani36@gmail.com;ablenzar@yahoo.fr
}

\begin{abstract}
Rhizomania is one of the most devastating diseases of sugar beet worldwide. The disease poses a serious threat to Moroccan production and it is capable of significantly decreasing quality and yield of sugar beet plantations. The long-term survival of its fungal vector (Polymyxa betae) in soil makes it a very difficult disease to manage. Therefore, this study investigated the potential of a non-pathogenic fungal Fusarium oxysporum strain Fo47 to control Polymyxa betae. This biocontrol agent was applied as soil treatment, seed treatment, or a combination of the both treatments. A bio-test was performed on treated soil. After four weeks of culture, the roots of sugar beet seedlings were retrieved and analyzed by the DAS-ELISA test. Results indicated that $F$. oxysporium Fo47 reduced the activity and survival of $P$. betae when compared to a reference biocontrol agent Trichoderma harzianum, which only revealed significant in reducing the viral load of Beet Necrotic Yellow Vein Virus (BNYVV) as seed treatment. The non-pathogenic Fusarium oxysporum Fo47 was more effective as soil treatment and allowed almost the same reduction of BNYVV virus concentration as T. harzianum 908. Therefore, our findings emphasizes that the performance of the biocontrol agent depends on the method of application.
\end{abstract}

Keywords: Beet Necrotic Yellow Vein Virus; biocontrol, Fusarium oxysporum strain Fo47; Trichoderma harzianum strain 908

\section{Introduction}

Sugar beet (Beta vulgaris L.) is considered one of the major important cultivated crops in many countries, including Morocco. This crop has gained popularity and importance over time due to its various uses as a food source for humans and animals. However, the occurrence of several diseases and outbreaks during recent years in Morocco resulted in economically important loss of sugar beet yield in many sites of production (Anonymous, 2005; Snaiki et al., 2005). Among them, Rhizomania is one of the most destructive diseases affecting sugar beet in Morocco. This disease was caused by Beet Necrotic Yellow Vein Virus (BNYVV) and sprayed over nature via the fungus Polymyxa betae Keskin (Brunt and Richards, 1989; Richards and Tamada, 1992; Van Regenmortel et al., 2000). Rhizomania has been reported to occur in many countries (Putz et al., 1990), and it is currently one of the most destructive sugar beet diseases in the world (Rush and Heidel, 1995; Scholten and Lange, 2000). The losses caused by rhizomania are usually over $30 \%$ and may even reach $100 \%$ in some cases (Asher, 1993).

To the best of our knowledge, this disease is difficult to control when it was declared and no such effective control method was found to date. Thus, common control strategies such as cultural control practices and soil disinfection showed their failures and the only way to control rhizomania is still the use of tolerant sugar beet varieties to the disease, however, the available tolerant varieties in the market were started showing their limitations. In addition, the manifestations of rhizomania on tolerant varieties were reported at several sites (ITB, 2010). This situation was partially explained by the lack of tolerance of some varieties, or higher pressure of the disease, due to one hot and wet spring and a more important presence of the Polymyxa, or even the appearance and increase of virulent pathotypes in the pathogen population (Schmit et al., 2002; Rush, 2003; Bornemann and Varrelmann, 2011).

During last decades, biological control has increased and gained more attention of researchers in order to overcome the resistance problems against common used synthetic 
138

substances fueled by public concerns over the long-term impact of these substances on the environment and human health, and the need to develop eco-friendly alternatives for disease control (Brunner et al., 2005; Haggag et al., 2006; Jin and Custis, 2011; Kakvan et al., 2013). In most cases, biological control of plant diseases relies on the use of effective bacterial and fungal antagonists (Heydari and Pessarakli, 2010; Naraghi et al., 2010a, b and c; Jorjani et al., 2011; Naraghi et al., 2012a and b; Mansouri et al., 2013). These microorganisms usually controlled their target pathogens by different mechanisms including antibiosis, mycoparasitism, and competition for space and nutrient (Whipps, 2001). Trichoderma spp. are among the most common saprophytic fungi extensively investigated for their biological control effects against fungal plant pathogen (Nelson, 2004; Woo and Lorito, 2007; Schuster and Schmoll, 2010; Kumar, 2013). Trichoderma members act on their targets by producing extracellular enzymes and antifungal substances, but they also may compete with pathogens fungus for nutrients and space to delay or prevent infection and subsequently enhance plant growth and development and induce plant resistance to disease (Shalini et al., 2006). However, many of $F$. oxysporum species are among pathogens threatening a wide range of cultivated plants, but few strains of this fungus are well recognized as biological control agents (BCAs). For example, the nonpathogenic strains Fo47, have the particularity to protect plants from pathogenic infection of the same fungus. The biocontrol activity of Fo47 strains is relatively specific and they can be used to manage Fusarium wilt (Fravel et al., 2003; Alabouvette et al., 2009). The role played by nonpathogenic Fusarium species in controlling Fusarium wilt was first reported by Smith and Snyder (1971) on sweet potato plants. In addition, Kaur et al. (2010) found that Fusarium-suppressive soil contain a higher level of nonpathogenic Fusarium population; suggesting their eventual role in reducing the pathogenic Fusarium population.

Although, numerous reports underlined the possibility of applying beneficial microorganisms to control plant diseases pathogens, the biocontrol of soil-borne pathogens was always difficult than that of aerial diseases (Divya Rani and Sudini, 2013). In addition to the two extensively studied groups of BCAs Pseudomonas spp. and Trichoderma spp., the non-pathogenic strains of Fusarium oxysporum represent an original model, which may lead to the development of an effective and reliable biofungicide for the control of soil-borne pathogens both in greenhouse and field conditions. However, to our knowledge, until now there were few investigations dealing with biocontrol of the fungal vector of rhizomania (Resca et al., 2001; Naraghi $e t$ al., 2014). Therefore, the main objectives of the present study were to investigate the ability of the non-pathogenic fungus Fusarium strain Fo47 to suppress fungal vector $P$. betae and to evaluate the impact of different application methods of BCA on the biocontrol efficacy of sugar beet rhizomania disease in Morocco. The Trichoderma harzianum strain 908 was used as BCA reference. This study is a part of the development of a biocontrol strategy against this devastating rhizomania disease.

\section{Materials and Methods}

\section{Laboratory experiments}

\section{Soil sampling for the greenhouse experiment}

Soil samples were collected from infected sugar beet fields with rhizomania in Souk Sebt Ouled Neema district, Beni Mellal, province. Field Sampling procedure was performed according to the standards recommended by the official method of virus detection rhizomania in sugar beet (anonymous, 2006). To ensure the infestation of the field soil by rhizomania, sugar beet tubers suspected to have the disease were removed from the fields and their thin rootlets were analyzed using an Enzyme Linked ImmunoSorbent Assay (ELISA) test. To ensure a homogeneous and important level of infestation, soil was mixed with sterile soil $(1: 1)$ and then soil was mixed with activated carbon $(0.673$ $\mathrm{g} /$ pot). Infested soil samples will be used further for the subsequent greenhouse experiments.

\section{Preparation of fungal biocontrol agents}

In this study, the hyperparasitic fungi $F$. oxysporum strain Fo47 and the BCA reference Trichoderma harzianum strain 908 were evaluated for their ability to reduce both rhizomania disease and fungal vector survival. Both fungi $F$. oxysporum strain Fo47 and T. harzianum strain 908 and were applied at a concentration of $1 \times 10^{6}$ $\mathrm{CFU} / \mathrm{g}$ and $1 \times 10^{7} \mathrm{CFU} / \mathrm{g}$ respectively.

\section{Greenhouse trial}

The trapping test was conducted according to the recommendations noted in "The official method of Detection of the virus in Rhizomania of beet by the biological test followed by the ELISA test" (Anonymous, 2010). To avoid contamination between samples, all sampling involved aseptic precautions were undertaken, including the use of sterile and disinfected instruments and disposable rubber gloves between each sample. betae

Effectiveness of fungal biocontrol agents in suppressing $P$.

The experiment was laid out in a randomized complete block-split plot design using the main factor (biocontrol agent) in four levels $(1-T$. harzianum; $2-F$. oxysporum; 3 - the uninfested control; and 4 - the infested control) and replicated at 6 different times, and the sub-factor (method of BCA application) in three forms (1-seed treatment, 2-soil treatment, and 3-a combination of the above-mentioned methods). Each replication consisted of a pot containing $150 \mathrm{ml}$ of infested sugar beet field soil with rhizomania. 20 seeds of the sugar beet susceptible cultivar ('Rhizopoly') were sown in each pot. The negative control (disease-free) was made with three pots of $150 \mathrm{ml}$ of sterilized soil, while other three pots filled with infested soil were served as positive control. The plants were maintained for four weeks in greenhouse with a $16 \mathrm{~h}$ daily photoperiod at $25^{\circ} \mathrm{C}$ and $50 \%$ relative humidity.

Virological analysis

Detection of BNYVV in sugar beet roots was performed using Double Antibody Sandwich - Enzyme Linked 
Immuno Sorbent Assay (DAS-ELISA) according to the protocol provided by the manufacture (SEDIAG, France). Each sample was tested in two replicates. Reading was done after incubation periods of $1 \mathrm{~h}$ and $2 \mathrm{~h}$ with substrate pNPP (p-nitrophenyl phosphate) at $37^{\circ} \mathrm{C}$. The microplates were analysed using a BioTek Elx $800^{\text {tim }}$ microplate reader.

\section{Statistical analysis of data}

All experiments are at least repeated twice and the collected data were subjected to analysis of variance (ANOVA) and the means were compared using Duncan's Multiple Range Test with statistical software SPSS (SPSS version 20). The level of significance was determined in different treatments at $1 \%$ probability.

\section{Results and Discussion}

In this study, the suppression of the occurrence of $P$. betae in form of 'cystosori' in beetroots was considered as a rough indication of the biocontrol efficiency of BCAs. On the other hand, the ELISA results of BNYVV in the roots were considered as main objective and were statistically evaluated. After four weeks of planting, the virological analysis of beet roots samples was made through DASELISA test. The obtained results showed that the activity of the fungal vector $P$. betae was negatively affected by BCAs $F$. oxysporum and $T$. harzianum.

The effect of the main factor of the BNYVV multiplication was significant at $\mathrm{P}<0.01$. When compared to the infested control, all the treatments containing antagonists showed a significant decrease in the proliferation of BNYVV (Table 1). There is no significant difference between the two antagonists. The treatments based on Fo47 and on Th908 demonstrated a higher significant decrease in the viral load of BNYVV, in comparison with those the infested control (Table 1). Th908 allowed a reduction of $47.6 \%$ of the proliferation of BNYVV compared to the positive control. As for the Fo47, a reduction of $44.7 \%$ was observed. Thus, it is obvious that the antagonistic effect of both fungi allows a decrease in the viral concentration (Table 1).

The effect of the sub-factor (method of antagonist application) on the proliferation of $P$. betae and multiplication of BNYVV was significant at $\mathrm{P}<0.01$. By considering that the optical density is proportional to the viral concentration, the results of the ANOVA showed that the proliferation of BNYVV was significantly reduced by the method of antagonist application as well as by both studied antagonists (Table 1 and 2).

Similarly, the effect of the combination of the main factor and sub-factor on sugar beet root weight was significant $(\mathrm{P}<0.01)$. There were four statistically different groups (Table 3). Among the treatments, the soil treatment based on Fo47 and the seed treatment based on Th908 showed the lowest optical density (OD). However, the highest OD was recorded for both seed and soil treatment and as affected by Th908 (Table 3). Furthermore, compared to the positive control, all antagonist treatments showed a significant decrease in the viral load (Table 3).

Amongst the different methods of antagonist application mentioned above, soil treatment by the fungus $F$. oxysporum resulted in a higher reduction of the proliferation of BNYVV. However, the seed treatment with T. harzianum allowed the most reduction of disease.

Table 1. Efficacy of the main factor (two antagonists: F. oxysporum and T. harzianum) in the suppression of BNYVV multiplication in greenhouse conditions

\begin{tabular}{|c|c|}
\hline Main factor & Optical density \\
\hline T. harzianum strain 908 & $0.55 \mathrm{~b}^{\mathrm{z}}$ \\
\hline F. oxysporum strain Fo 47 & $0.58 \mathrm{~b}$ \\
\hline The infested control & $1.05 \mathrm{a}$ \\
\hline The healthy control & $0.13 \mathrm{c}$ \\
\hline
\end{tabular}

Table 2. Efficacy of the sub-factor (different application methods of T. harzianum strain 908 and F. oxysporum strain Fo47) in the suppression of $B N Y V V$ multiplication in greenhouse conditions

\begin{tabular}{cc}
\hline Sub-factor & Optical density \\
\hline Soil treatment & $0.45 \mathrm{~b}^{\mathrm{z}}$ \\
Seed treatment & $0.53 \mathrm{~b}$ \\
Soil and seed treatment & $0.72 \mathrm{a}$ \\
\hline${ }^{\mathrm{T}}$ Values marked with different letters in the columns are statistically different according to Duncan's multiple range test (p $\left.\leq 0.01\right)$.
\end{tabular}

Table 3. Efficacy of a combination of the main (different application methods of T. harzianum strain 908 and F. oxysporum strain Fo47) and the subfactor (two antagonists: T. harzianum and F. oxysporum) in the suppression of BNYVV multiplication in greenhouse conditions

\begin{tabular}{cc}
\hline Treatment & Optical density \\
\hline T. harzianum-soil & $0.49 \mathrm{~b}^{\mathrm{z}}$ \\
F. oxysporum-soil & $0.42 \mathrm{~b}$ \\
T. harzianum-seed & $0.42 \mathrm{~b}$ \\
F. oxysporum-seed & $0.65 \mathrm{c}$ \\
T. harzianum soil and seed & $0.75 \mathrm{c}$ \\
F. oxysporum soil and seed & $0.69 \mathrm{c}$ \\
The infested control & $1.05 \mathrm{a}$ \\
The healthy control & $0.13 \mathrm{~d}$ \\
\hline${ }^{\mathrm{T}}$ Values marked with different letters in the columns are statistically different according to Duncan's multiple range test $(\mathrm{p} \leq 0.01)$.
\end{tabular}


The performance of the biocontrol agent depends on the method of application. The non-pathogenic strain of $F$. oxysporum Fo47 allowed a comparable concentration of BNYVV virus in the roots of the sugar to that recorded with T. harzianum 908.

Until now, no study was done on the biocontrol of the fungal vector of sugar beet rhizomania in Morocco. Our study is the first report on the ability of the non-pathogenic fungus $F$. oxysporum in suppressing rhizomania disease. In fact, there was no report about the use of this fungus as BCA against this devastating disease. The reduction of resting structure of the fungal vector by antagonist treatments was in line with previous findings reported in few studies with bacterial and fungal agents. For example, using antagonistic isolates of T. harzianum, D'Ambra and Mutto (1986) found that Trichoderma isolates were able to parasitize and decompose the resting structures of the fungal vector. Similarly, Aksoy and Yilmazz (2008) demonstrated that Pseudomonas putida biotypes A and B reduced the population of disease fungal vector by $23 \%$ and $75 \%$, respectively. Two non-pathogenic strains of $F$. oxysporum CS-20 and Fo47 have demonstrated their ability to protect the plants from the infection by the aggressive isolates of the same fungus (Kaur et al., 2010; Shcherbakova et al., 2015). Our results showed also the capability of $F$. oxysporum strain Fo47 to control the fungus $P$. betae. Alabouvette et al. (2009) reported the effectiveness of non-pathogenic strains of $F$. oxysporum in controlling Fusarium wilt.

Among the different methods of antagonist application mentioned above, soil treatment by the fungus $F$. oxysporum resulted in a higher reduction of the proliferation of BNYVV. However, the seed treatment with $T$. harzianum allowed the most reduction of disease. Camporta $e t$ al. (1988) have disclosed that seed-coating preparations with a conidial suspension were the best solution because it allows economies the amount of the biological agent. The technique of coating allows the antagonist to colonize the rhizosphere and the root system. Naraghi et al. (2014) evaluated the impact of applying $T$. harzianum as soil and seed treatment in controlled conditions and highlighted that the soil treatment was more effective in reducing the $P$. betae population.

In the present study, the soil treatment method was shown to be far effective than the combination of seed and soil treatments in reducing the infestation of disease. This can be explained by a "crowding effect" phenomenon as previously reported by Chitarra (2003) on Aspergillus and Penicillium fungi. Under greenhouse conditions, Jakubikova et al. (2010) pointed out that $T$. harzianum isolates with an inhibition rate of $21-68 \%$ toward the pathogenic virus (BNYVV). The results of the previous studies have also shown that BCAs are effective against damping- off, root rot, and wilt diseases of ornamental plants, vegetables and cereals (Whipps, 2001; Asef et al., 2008; Naraghi et al., 2010a, b, c; Godhani, 2011; Ojaghian, 2011).

\section{Conclusions}

Overall, the results reported in this study indicated the possibility of using beneficial microorganisms to decrease rhizomania disease on sugar beet by lowering the population of its fungal vector as well as the multiplication of BNYVV. The non-pathogenic strain of Fusarium oxysporum Fo47 provided the same concentration of BNYVV virus in the roots of the sugar beet as Th908. The performance of the biocontrol agent depends on the method of application. The soil treatment method was revealed most efficient in suppressing the multiplication of BNYVV and the proliferation of $P$. betae population.

Our study is the first report on the ability of the nonpathogenic fungus $F$. oxysporum strain Fo47 in suppressing rhizomania disease. In fact, there was no report about the use of this fungus as BCA against this devastating disease. Therefore, results of the present study may have a practical application in the formulation of an integrated and ecofriendly management strategy for the control of sugar beet rhizomania in sugar beets growing areas, including Morocco.

\section{Acknowledgements}

This work was supported by the Phytopathology Unit, Department of Plant Protection and Environment of the Ecole Nationale d'Agriculture de Meknès (Morocco).

\section{References}

Aksoy HM, Yilmazz NDK (2008). Antagonistic effects of natural Pseudomonas putida biotypes on Polymyxa betae Keskin, the vector of beet necrotic yellow vein virus in sugar beet. Journal of Plant Disease Protection 115:241-246.

Alabouvette C, Olivain C, Migheli Q, Steinberg C (2009).Microbiological control of soil-borne phytopathogenic fungi with special emphasis on wilt-inducing Fusarium oxysporum. New Phytologist 184:529-544.

Anonymous (2005). Premier signalement du beet necrotic yellow vein benyvirus au Maroc [First report of beet necrotic yellow vein benyvirus in Morocco].EPPO Bulletin Service d'Information 7:11.

Anonymous (2006). Beet necrotic yellow vein virus (benyvirus). Bulletin OEPP/EPPO Bulletin 36:429-440.

Anonymous (2010).Détection du virus dela rhizomanie de la betterave, beet necrotic yellow vein virus (BNYVV) Test biologique: MOA 011 partie $A$ version la [Detection of beet rhizomania virus, beet necrotic yellow vein virus (BNYVV) Biological test: MOA 011 part A version 1a].

Asef MR, Goltapeh GM, Danesh YR (2008). Antagonistic effects of Trichoderma species in biocontrol of Armillaria mellea in fruit trees in Iran.Journal of Plant Protection Research 48(2):213-222.

Asher MJC (1993). Rhizomania. In: The sugar beet crop. Cooke DA, Scott RK (Eds). Chapman and Hall, London, Oxford University Press, New Yorkpp311-346. 
Bornemann K, Varrelmann M (2011). Analysis of the resistance-breaking ability of different beet necrotic yellow vein virus isolates loaded into a single Polymyxa betae population in soil. Phytopathology 101:718-724.

Brunner K, Zeilinger S, Ciliento R, Woo SL, Lorito M, Kubicek CP, Mach RL (2005). Improvement of the fungal biocontrol agent Trichoderma atroviride to enhance both antagonism and induction of plant systemic disease resistance. AppliedandEnvironmental Microbiology 71:3959-3965.

Brunt AA, Richards K (1989). Biology and molecular biology of furoviruses. Advances in Virus Research 36:1-32.

Camporota P, Bordei V, Richard-Molard M (1988). Lutte biologique contre Polymyxa betae (Keskin) au moyen de Trichoderma sp. Résultats préliminaires in vivo [Biological control of Polymyxa betae (Keskin) using Trichodermasp. Preliminary results invivo]. Agronomie 8:223-225.

Chitarra GS (2003). Germination inhibitors of fungal spores: Identification and mode of action. Ph.D. Thesis, Wageningen University, Wageningen, The Netherlands, pp 120.

D'Ambra V, Mutto S (1986). Parassitismo di Trichoderma harzianum sucistosori di Polymyxa betae [Parasitism of Trichoderma harzianum sucistosori of Polymyxa betae]. Journal of Phytopathology 115:61-72.

Divya Rani V, Sudini H (2013). Management of soilborne diseases in crop plants: an overview.International Journal of Plant, Animal and Environmental Sciences 3:156-164.

Fravel DR, Olivan C, Alabouvette C (2003b).Fusarium oxysporum and its biocontrol. New Phytologist 157:493-502.

Godhani PH (2011). Evaluation of two antagonists against wilt disease of chickpea. Karnataka Journal of Agriculture Science 23:795-797.

Haggag WM, Kansoh AL, Aly AM (2006). Proteases from Talaromyces flawus and Trichoderma harzianum purification, characterization and antifungal activity against brown spot disease on faba bean. Plant Pathology Bulletin 15:231-239.

Heydari A, Pessarakli M (2010). A review on biological control of fungal plant pathogens using microbial antagonists. Journal Biological Science 10:273-290.

ITB (2010). Nématode à kystes et rhizomanie: quelle gestion durable ? La technique betteravière [Nematode with cysts and rhizomania: what sustainable management? The sugar beet technique].ITB, $\mathrm{N}^{\circ} 935 \mathrm{du} 21$ Septembre 2010.

Jakubilkova L, Subikova V, Nemkovic M, Farkas V (2010). Selection of natural isolates of Trichoderma spp. for biocontrol of Polymyxa betae as a vector of virus causing rhizomania sugar beet. Biologia 61:347-351.

Jin X, Custis D (2011). Biological control microencapsulating aerial conidia of Trichoderma harzianum through spray drying at elevated temperatures. Biological Control 56:202-208.

Jorjani M, Heydari A, Zamanizadeh H, Rezaee S, Naraghi L (2011). Development of Pseudomonas fluorescens and Bacillus coagulans based bioformulations using organic and inorganic carriers and evaluation of their influence on growth parameters of sugar beet. Journal of Biopesticides 4:180-185.

Kakvan N, Heydari A, Zamanizadeh HR, Rezaee S, Naraghi L (2013). Development of new bioformulation using Trichoderma and Talaromyces fungal antagonists for biological control of sugar beet damping-offdisease. Crop Protection 53:80-84.
Kaur R, Kaur J, Singh RS (2010). Nonpathogenic Fusarium as a biological control agent. Plant Pathology Journal 9:79-91.

Kumar S (2013). Trichoderma: a biological weapon for managing plant diseases and promoting sustainability. International Journal of Agriculture Science and Medical Veterinary 1:106-121.

Mansouri M, Heydari A, Hassanzadeh N, Rezaee S, Naraghi L (2013). Evaluation of Pseudomonas and Bacillus bacterial antagonists for biological control of cotton Verticillium wilt disease. Journal of Plant Protection Research 53:154-157.

Naraghi L, Heydari A, Askari H, Pourrahim R, Marzban R (2014). Biological control of Polymyxa betae, fungal vector of rhizomania disease of sugar beets in greenhouse conditions. Journal of Plant Protection Research 54:109-114.

Naraghi L, Heydari A, Rezaee S, Razavi M (2012a). Biocontrol agent Talaromyces flavus stimulates the growth of cotton and potato. Journal of Plant Growth Regulation 31:471-477.

Naraghi L, Heydari A, Rezaee S, Razavi M, Afshari-Azad H (2010a). Biological control of greenhouse cucumber Verticillium wilt disease by Talaromycesflauru. Phytopathologia Mediterranea 49:321-329.

Naraghi L, Heydari A, Rezaee S, Razavi M, Afshari-Azad H (2012b). Promotion of growth characteristics in greenhouse cucumber and tomato by Talaromyces flavus. International Journal of Agricultural Science Research 2:129-141.

Naraghi L, Heydari A, Rezaee S, Razavi M, Jahanifar H (2010b). Study on antagonistic effects of Talaromyces flawus on Verticilliumalbo-atrum, the causal agent of potato wilt disease. Crop Protection 29:658-662.

Naraghi L, Heydari A, Rezaee S, Razavi M, Jahanifar H, Mahmoodi Khaledi E (2010c). Biological control of tomato Verticillium wilt disease by Talaromycesflawus. Journal of Plant Protection Research 50:360-365.

Nelson EB (2004). Biological control of oomycete and fungal pathogens. In: Goodman RM (Ed). Encyclopedia of Plant and Crop Science. Marcel DekkerIncpp 137-140.

Ojaghian M (2011). Potential of Trichoderma spp. and Talaromyces flavus for biological control of potato stem rot caused by Sclerotinia sclerotiorum. Phytoparasitica 39:185-193.

Putz C, Merdinoglu D, Lemaire O, Stocky G, Valentin P, Weidemann S (1990). Beet necrotic yellow vein virus, causal agent of sugar beet rhizomania. Review of Plant Patholology 69:247-254.

Resca R, Basaglia M, Poggiolini S, Vian P, Bardin S, Walsh UF, Enriquez Barreiros CM, O'Gara F, Nuti MP, Casella S, Peruch U (2001). An integrated approach for the evaluation of biological control of the complex Polymyxa betae/Beet Necrotic Yellow Vein Virus, by means of seed inoculants. Plant and Soil 232:215-226.

Richards KE, Tamada T (1992). Mapping functions on the multipartite genome of beet necrotic yellow vein virus. Annual Review of Phytopathology 30:291-313.

Rush CM (2003). Ecology and epidemiology of benyviruses and plasmodiophorid vectors. Annual Review of Phytopathology 41:567592.

Rush CM,Heidel GB (1995). Furovirus diseases of sugar beets in the United States. Plant Disease 79:868-875.

Schmit JF, Meunier A, Stas A, Legrève A, Bragard C, Wauters A (2002). 
142

Véritable explosion de la rhizomanie en 2002 [Real explosion of rhizomania in 2002]. Le Betteravier 388:8-10.

Scholten OE, Lange W (2000). Breeding for resistance to rhizomania in sugar beet: A review. Euphytica 112:219-231.

Schuster A, Schmoll M (2010). Biology and biotechnology of Trichoderma. Applied Microbiology and Biotechnology 87:787-799

Shalini N, Lata KP, Kotasthane AS (2006). Genetic relatedness among Trichoderma isolates inhibiting a pathogenic fungi Rbizoctonia solani. African Journal of Biotechnology 5:580-584.

Shcherbakova LA, Odintsova TI, Stakheev AA, Fravel DR, Zavriev SK (2015). Identification of a novel small cysteine-rich protein in the fraction from the biocontrol Fusarium oxysporum strain CS-20 that mitigates Fusarium wilt symptoms and triggers defense responses in tomato. Frontiers in Plant Science6.

Smith SN, Snyder WC (1971). Relationship of inoculum density and soil types to severity of fusarium wilt of sweet potato. Phytopathology 61:1049-1051.
Snaiki J, Nadif A, Ouhssine M (2005). Détection de deux pathotypes d'Erwinia causant la maladie de la pourriture molle sur la betterave à sucre dans la plaine du Gharb au Maroc [Detection of two Erwinia pathotypes causing soft rot on sugar beet in the Gharb plain in Morocco].EPPOBulletin 35:537-540.

Van Regenmortel MHV, Fauquet CM, Bishop DHL, Carstens EB, Estes MK, Lemon SM, Maniloff J, Mayo MA, Mc-Geoch DJ, Pringle CR, Wickner RB (2000). Virus taxonomy: Seventh report of the international committee on taxonomy of viruses. Academic Press, San Diego, California.

Whipps JM (2001). Microbial interactions and biocontrol in the rhizosphere. Journal of Experimental Botany 52:487-511.

Woo SL, Lorito M (2007). Exploiting the interactions between fungal antagonists, pathogens and the plant for biocontrol. In Novel Biotechnologies for Biocontrol Agent Enhancement and Management. Springer Netherlands pp 07-130. 